\title{
PENERAPAN GOOD DAIRY FARMING PRACTICE (GDFP) DAN PENDAPATAN USAHA TERNAK SAPI PERAH KEMITRAAN DAN MANDIRI DI KABUPATEN JEMBER \\ THE IMPLEMENTATION OF GOOD DAIRY FARMING PRACTICE (GDFP) AND INCOME OF PARTNERSHIP AND INDEPENDENT DAIRY FARM BUSINESSES IN JEMBER REGENCY
}

\author{
Siti Aminah ${ }^{1}$, M. Rondhi ${ }^{2}$ \\ ${ }^{1}$ Mahasiswa Program Studi Agribisnis, Fakultas Pertanian, Universitas Jember \\ ${ }^{2}$ Dosen Program Studi Agribisnis, Fakultas Pertanian, Universitas Jember \\ email: Sitiaminah.yasmin@gmail.com;081234075986
}

\begin{abstract}
Increased demand of milk is higher along with the increasing number of population, but increased demand of milk is less offset by increased production of local dairy cow milk so that in fulfilling local milk need is still doing a lot of milk import. With the existing of milk demand, livestock farming development of dairy cows can be done in Jember Regency. One of dairy cow farming in Jember Regency is located in Kemuning Lor Village Arjasa District Jember Regency which is the independent farm. Partnership farm in Jember Regency is in Ajung Village Ajung District, Balung Lor Village Balung District and Rowotengah Village Sumberbaru District which are partnership farm with Galur Murni Cooperative. Both livestock businesses experience the same problem which is the lows of milk production so that causes the lows of income received by the farmer. Milk production can increase if the farmer can apply GDFP (Good Dairy Farming Practice) of good dairy cows. This research aimed to (1) find out GDFP implementation, (2) find out the income, and (3) find out cost use efficiency. This research showed that: (1) The level of GDFP implementation of partnership farm was higher than the level of GDFP implementation of the independent farm. (2) Both livestock businesses of partnership and independent farm in Jember Regency is mutual. The amount of income per tail of partnership dairy cows was IDR 8,895,762/year and the net income per tail of independent dairy cows was IDR 11,635,231/year, (3) The cost use efficiency on partnership and independent dairy farm businesses was all efficient. The efficiency value of the $R / C$ ratio of partnership dairy farm business was 1.25 while the efficiency value of the $R / C$ ratio of the independent dairy farm was 1.18.
\end{abstract}

Keywords: Dairy Cows, GDFP Implementation, Income, Efficiency of R/C Ratio

\begin{abstract}
ABSTRAK
Peningkatan permintaan susu semakin tinggi seiring dengan bertambahnya jumlah penduduk, akan tetapi peningkatan permintaan susu kurang diimbangi dengan peningkatan produksi susu sapi perah dalam negeri sehingga dalam memenuhi kebutuhan susu dalam negeri masih banyak melakukan impor susu. Dengan adanya permintaan susu yang tinggi tersebut dapat di lakukan pengembangan usaha peternakan sapi perah di Kabupaten Jember. Salah satu peternakan sapi perah di Kabupaten Jember yaitu berada di Desa Kemuning Lor Kecamatan Arjasa Kabupaten Jember yang merupakan peternakan mandiri. Peternakan mitra di Kabupaten Jember berada di Desa Ajung Kecamatan Ajung, Desa Balung Lor Kecamatan Balung dan Desa Rowotengah Kecamatan Sumberbaru yang merupakan peternak mitra dengan Koperasi Galur Murni. Kedua usaha peternakan tersebut mengalami permasalahan yang sama yaitu rendahnya produksi susu
\end{abstract}


sehingga menyebabkan rendahnya pendapatan yang diterima peternak. Produksi susu dapat ditingkatkan apabila peternak dapat menerapkan GDFP (Good Dairy Farming Practice) sapi perah yang baik. Tujuan dari penelitian ini adalah untuk mengetahui: (1) penerapan GDFP peternak sapi perah, (2) pendapatan, dan (3) efisiensi penggunaan biaya. Hasil penelitian menunjukkan bahwa: (1) Tingkat penerapan GDFP peternak kemitraan lebih tinggi dari pada tingkat penerapan GDFP peternak mandiri. (2) Kedua usaha peternakan sapi perah baik kemitraan maupun mandiri di Kabupaten Jember sama-sama menguntungkan. Besarnya pendapatan per ekor sapi perah peternak kemitraan sebesar Rp 8.895.763/tahun dan pendapatan bersih per ekor sapi perah peternak mandiri sebesar Rp 11.635.231/tahun, (3) Efisiensi penggunaan biaya pada usaha ternak sapi perah kemitraan dan mandiri sama-sama efisien. Nilai efisiensi $\mathrm{R} / \mathrm{C}$ rasio usaha peternakan sapi perah kemitraan sebesar 1,25 sedangkan nilai efisiensi $\mathrm{R} / \mathrm{C}$ rasio usaha peternakan mandiri sebesar peternak mandiri sebesar 1,18.

Kata Kunci : Sapi perah, Penerapan GDFP, Pendapatan, dan Efisiensi R/C Rasio

\section{PENDAHULUAN}

Menurut Otoluwa dkk (2016), menyatakan bahwa subsektor peternakan memiliki peranan yang cukup strategis utamanya dari kontribusi terhadap: (a) produk domestik bruto, (b) penyerapan tenaga kerja, (c) memenuhi kebutuhan protein hewani, (d) penyedia pakan, (e) bahan baku industri serta (f) sebagai sumber pendapatan bagi masyarakat dipedesaan. Salah satu komoditas subsektor peternakan yaitu sapi. Terdapat dua cara dalam pengembangan sapi yaitu: (a) sapi perah dan (b) sapi potong. Keunggulan komoditas sapi perah dibandingkan sapi potong yaitu prospek bisnis sapi perah lebih menarik dibandingkan sapi potong yaitu pendapatannya harian sedangkan pendapatan sapi potong masih menunggu sekitar empat bulan.

Peternakan sapi perah merupakan salah satu pilar yang turut andil dalam menopang kebutuhan manusia akan terpenuhinya protein hewani. Produk utama dari sapi perah yaitu susu. Susu sapi perah merupakan salah satu bahan pangan yang sangat penting dalam hal mencukupi kebutuhan gizi masyarakat karena susu memiliki kandungan gizi yang tinggi. Peningkatan permintaan susu semakin tinggi seiring dengan bertambahnya jumlah penduduk, akan tetapi peningkatan permintaan susu kurang diimbangi dengan peningkatan produksi susu sapi perah dalam negeri sehingga dalam memenuhi kebutuhan susu dalam negeri masih banyak melakukan impor susu (Kementerian Pertanian, 2016).

Tabel 1. Produksi Susu Segar Indonesia (Ton)

\begin{tabular}{crc}
\hline Tahun & Produksi Susu Segar (Ton) & Pertumbuhan*(\%) $^{*}$ \\
\hline 2013 & $786.849,00$ & - \\
2014 & $800.749,00$ & 1,77 \\
2015 & $835.124,60$ & 4,29 \\
2016 & $912.735,00$ & 9,29 \\
2017 & $920.093,43$ & 0,81 \\
\hline Rata-Rata & $\mathbf{8 6 7 . 1 7 5 , 5 1}$ & $\mathbf{4 , 0 4}$ \\
\hline
\end{tabular}

Sumber: Badan Pusat Statistik (2018)

Keterangan: *Diolah oleh penulis

Tabel 1 menunjukkan data jumlah produksi susu segar yang tersebar di seluruh wilayah Indonesia. Berdasarkan Tabel 1, dapat diketahui bahwa produksi susu segar di Indonesia mulai tahun 2013 hingga tahun 2017 mengalami peningkatan produksinya. Produksi susu segar di Indonesia mulai tahun 2013 hingga 2017 menunjukkan rata-rata pertumbuhan yang positif atau meningkat yaitu sebesar 4,04\%.

Kabupaten Jember merupakan salah satu kabupaten yang melakukan pengembangan usaha peternakan sapi perah. Menurut Wirawan (2015) dalam Isnia dkk (2017), menyatakan bahwa masalah utama pada peternakan sapi perah di Kabupaten Jember adalah bibit, pakan dan manajemen pemeliharaan. Pemeliharan dan pakan yang baik nantinya akan meghasilkan produksi susu yang baik dengan didukung oleh pembibitan yang baik pula. Adapun di Kabupaten Jember, terdapat dua kategori peternakan sapi perah yaitu: (a) peternakan mandiri 
dan (b) peternakan bermitra. Salah satu peternakan sapi perah di Kabupaten Jember yaitu berada di Desa Kemuning Lor Kecamatan Arjasa Kabupaten Jember yang merupakan peternakan mandiri. Usaha ternak mandiri dilakukan oleh peternak sapi perah dengan cara menyediakan semua sarana produksi secara mandiri, sehingga peternak memiliki kebebasan menjual hasil produksinya. Harga susu peternak mandiri yang di jual ke loper berkisar antara Rp 6.000 hingga Rp 7.000/liter. Peternakan sapi perah mitra di Kabupaten Jember salah satu diantara nya berada di Desa Ajung Kecamatan Ajung, Desa Balung Lor Kecamatan Balung dan Desa Rowotengah Kecamatan Sumberbaru yang merupakan peternak sapi perah mitra dengan Koperasi Galur Murni. Harga susu peternak mitra di Koperasi Galur Murni tergantung dari kualitas susu yang dihasilkan. Harga susu sapi perah pada Koperasi Galur Murni berkisar mulai dari Rp 4.500/liter hingga $\mathrm{Rp}$ 5.000/liter.

Kedua usaha peternakan sapi perah tersebut relatif mengalami permasalahan yang sama yaitu rendahnya produksi susu sehingga menyebabkan rendahnya pendapatan yang diterima peternak. Selain itu pada saat musim kemarau, peternak mengalami kesulitan dalam pencarian pakan, sehingga peternak akan memperbanyak pemberian pakan ampas tahu. Pemberian jumlah pakan yang berbeda tersebut akan menyebabkan produksi susu rendah. Seperti kita ketahui bahwa peternakan sapi perah membutuhkan biaya yang tinggi, oleh karena itu apabila biaya yang dikeluarkan banyak dan poduksi susu yang dihasilkan rendah maka akan berpengaruh terhadap efisiensi penggunaan biaya.

Produksi susu dapat ditingkatkan apabila peternak dapat menerapkan GDFP (Good Dairy Farming Practice) sapi perah yang baik. GDFP (Good Dairy Farming Practice) adalah suatu standarisasi usaha peternakan sapi perah yang apabila dilaksanakan dengan baik maka tingkat keuntungan peternak akan selalu dapat dipertahankan. Oleh karena itu maka perlu diketahui tingkat penerapan GDFP, pendapatan serta efisiensi penggunaan biaya. Berdasarkan latar belakang diatas, peneliti ingin mengetahui: (1) seberapa besar penerapan GDFP (Good Dairy Farming Practice) pada peternak kemitraan dan mandiri di Kabupaten Jember, (2) apakah peternak sapi perah yang menjalin kemitraan dan yang mandiri di Kabupaten Jember menguntungkan,(3) apakah penggunaan biaya usaha ternak yang menjalin kemitraan dan yang mandiri di Kabupaten Jember efisien?

\section{METODE PENELITIAN}

Penentuan daerah penelitian dilakukan dengan menggunakan metode purposive method atau secara sengaja dengan pertimbangan tertentu sehingga daerah tersebut layak dijadikan tempat penelitian. Metode penelitian yang digunakan adalah analitik dan deskriptif. Metode pengambilan contoh dilakukan dengan metode sensus. Metode sensus dapat digunakan apabila jumlah populasi relatif sedikit yakni kurang dari 30. Total sampel penelitian ini sebanyak 22 orang peternak sapi perah mitra Koperasi Galur Murni dan 6 orang peternak sapi perah mandiri di Kabupaten Jember. Sehingga total peternak sapi perah mitra dan peternak sapi perah mandiri di Kabupaten Jember yang di jadikan sampel dalam penelitian ini sebanyak 28 orang peternak. Metode pengumpulan data menggunakan wawancara dan observasi.

Metode analisis data yang digunakan untuk mengetahui penerapan GDFP peternak sapi perah menggunakan pendekatan metode deskriptif. Aspek yang akan di ukur dalam penerapan GDFP peternak sapi perah terdiri dari aspek kesehatan ternak, aspek manajemen pemerahan, aspek nutrisi (pakan dan air), aspek kesejahteraan ternak, aspek lingkungan dan aspek manajemen sosial ekonomi. Metode analisis data yang digunakan untuk mengetahui pendapatan usaha ternak sapi perah menggunakan analisis pendapatan. Untuk mengetahui pendapatan peternak, maka harus mengetahui total penerimaan dan total biaya. Total penerimaan di analisis menggunakan rumus sebagai berikut:

$$
\mathrm{TR}=\mathrm{P} . \mathrm{Q}
$$

Keterangan : TR $=$ Total revenue (total penerimaan susu)

$$
\begin{aligned}
\mathrm{P} & =\text { Harga (Rp/liter) } \\
\mathrm{Q} & =\text { Kuantitas atau jumlah susu (liter) }
\end{aligned}
$$


Menurut Sulthoni (2008) dalam Londa dkk (2013), bahwa sumber penerimaan terbesar dalam usaha ternak sapi perah adalah penjualan susu. Penerimaan yang berasal dari penjualan susu dipengaruhi oleh jumlah ternak yang dimiliki. Semakin banyak ternak yang dimiliki maka produksi susu yang dihasilkan semakin banyak sehingga dapat berpengaruh terhadap penjualan susu. Total biaya akan di analisis dengan menggunakan rumus sebagai berikut (Soetriono, 2015):

Keterangan : $\mathrm{TC}=$ biaya total (total cost)

$$
\mathrm{TC}=\mathrm{FC}+\mathrm{VC}
$$

$\mathrm{FC}=$ biaya tetap (fixed cost)

$\mathrm{VC}=$ biaya variabel (variabel cost)

Perhitungan penyusutan dalam penelitian ini mengunakan metode garis lurus tanpa nilai residu dengan asumsi peralatan tidak dapat dijual setelah habis umur ekonomis. Penyusutan menggunakan metode garis lurus dirumuskan sebagai berikut (Herry (2014) dalam Sari (2018)):

Penyusutan $(\mathrm{Rp})=$ nilai beli : umur ekonomis

Adapun analisis pendapatan usaha ternak sapi perah akan dianalisis dengan menggunakan pendekatan sebagai berikut (Soetriono, 2015):

$$
\begin{aligned}
\text { Keterangan : } \pi & =\text { Pendapatan } \quad \pi=\mathrm{TR}-\mathrm{TC} \\
\mathrm{TR} & =\text { Total penerimaan (P.Q) }(\mathrm{Rp} / \mathrm{liter}) \\
\mathrm{P} & =\text { Harga output susu (Rp/liter) } \\
\mathrm{Q} & =\text { Jumlah produksi (liter) } \\
\mathrm{TC} & =\text { Total biaya (TFC }+\mathrm{TVC}) \\
\mathrm{TFC} & =\text { Total biaya tetap (Rp) } \\
\mathrm{TVC} & =\text { Total biaya variabel }(\mathrm{Rp})
\end{aligned}
$$

Metode analisis data yang digunakan untuk mengetahui efisiensi penggunaan biaya peternak sapi perah dilakukan menggunakan analisis efisiensi biaya $\mathrm{R} / \mathrm{C}$ rasio, dengan rumus sebagai berikut:

Dimana: $\mathrm{R}=$ Penerimaan $(\mathrm{Rp} / \mathrm{liter})$

$$
\begin{aligned}
& \mathrm{a}=\mathrm{R} / \mathrm{C} \\
& \mathrm{R}=\mathrm{Py} . \mathrm{Y} \\
& \mathrm{C}=\mathrm{FC}+\mathrm{VC} \\
& \mathrm{a}=((\mathrm{Py} . \mathrm{Y}) /(\mathrm{FC}+\mathrm{VC}))
\end{aligned}
$$

$$
\begin{aligned}
\mathrm{C} & =\text { Biaya }(\mathrm{Rp}) \\
\mathrm{Py} & =\text { Harga output }(\text { susu })(\mathrm{Rp} / \mathrm{liter}) \\
\mathrm{Y} & =\text { Output }(\text { susu) }(\text { liter }) \\
\mathrm{FC} & =\text { Biaya tetap }(\text { fixed cost) }(\mathrm{Rp}) \\
\mathrm{VC} & =\text { Biaya variabel }(\text { Variabel cost) }(\mathrm{Rp})
\end{aligned}
$$

Kriteria pengambilan keputusan:

Jika $\mathrm{R} / \mathrm{C} \leq 1$, maka penggunaan biaya ternak sapi perah tidak efisien/ tidak layak.

Jika R/C > 1, maka penggunaan biaya ternak sapi perah efisien/layak.

\section{HASIL DAN PEMBAHASAN}

\section{Penerapan GDFP (Good Dairy Farming Practice) Peternak Sapi Perah Kemitraan dan Mandiri Kabupaten Jember}

Good Dairy Farming Practice sapi perah yang dimaksud pada penelitian ini merupakan tata cara beternak sapi perah yang baik dan diterapkan pada peternakan sapi perah yang menjalin kemitraan dengan Koperasi Galur Murni dan peternakan mandiri di Kabupaten Jember. Koperasi Galur Murni memiliki tiga lokasi penampungan susu yang berada di Kabupaten Jember, ketiga lokasi tersebut berada di Desa Ajung Kecamatan Ajung, Desa Balung Lor Kecamatan Balung dan Desa Rowotengah Kecamatan Sumberbaru. Ruang lingkup penelitian ini hanya dibatasi pada peternak yang aktif menyetor susu setiap hari nya ke Koperasi Galur Murni dan peternak yang masih aktif mengusahakan ternak sapi perah di Desa Kemuning Lor Kecamatan Arjasa. Good dairy farming practice dibagi dalam enam aspek. Keenam aspek 
tersebut terdiri dari kesehatan ternak, manajemen pemerahan, nutrisi, kesejahteraan ternak, lingkungan dan manajemen sosial ekonomi.

\section{Aspek Kesehatan Ternak}

Manajemen kesehatan ternak pada peternakan sapi perah bertujuan untuk menjamin susu yang dihasilkan aman dan layak di konsumsi serta mengontrol penyakit pada ternak sapi perah. Ternak yang sehat mampu memproduksi susu yang optimal (Anggraeni dan Mariana, 2016). Berikut merupakan tabel terkait aspek kesehatan ternak.

Tabel 2. Persentase Aplikasi GDFP Aspek Kesehatan Ternak pada Peternak Sapi Perah Kemitraan dan Mandiri di Kabupaten Jember

\begin{tabular}{lrcrc}
\hline \multicolumn{1}{c}{$\begin{array}{c}\text { Sub Aspek } \\
\text { Kesehatan Ternak }\end{array}$} & $\begin{array}{c}\text { Peternak } \\
\text { Kemitraan }\end{array}$ & $\begin{array}{c}\text { Persentase } \\
(\mathbf{\%})\end{array}$ & $\begin{array}{c}\text { Peternak } \\
\text { Mandiri }\end{array}$ & $\begin{array}{c}\text { Persentase } \\
(\boldsymbol{\%})\end{array}$ \\
\hline $\begin{array}{l}\text { Sapi tahan terhadap cuaca } \\
\text { panas }\end{array}$ & 22 & $100,00 \%$ & 6 & $100,00 \%$ \\
$\begin{array}{l}\text { Sapi bebas dari penyakit } \\
\begin{array}{l}\text { Memeriksa ternaknya } \\
\text { secara teratur }\end{array}\end{array}$ & 22 & $100,00 \%$ & 6 & $100,00 \%$ \\
\hline Total Menerapkan & 22 & $100,00 \%$ & 6 & $100,00 \%$ \\
\hline
\end{tabular}

Sumber: Data primer diolah (2019)

Persentase penerapan GDFP sapi perah dari aspek kesehatan ternak pada peternakan mitra dan peternakan mandiri keduanya sebesar $100 \%$. Peternak memilih sapi perah yang cocok dan sesuai dengan lingkungan setempat. Jenis sapi yang digunakan peternak untuk melakukan ternak sapi perah yaitu sapi perah Friesian Holstein dan peranakannya. Sebelum peternak membeli ternak sapi perah yang baru, peternak akan memastikan terlebih dahulu apakah ternak sapi perah tersebut sehat serta bebas penyakit guna mencegah kemungkinan terjadinya penularan penyakit pada ternak yang lain. Peternak sapi perah mitra dan peternak sapi perah mandiri di Kabupaten Jember juga memeriksa ternaknya secara teratur dengan cara peternak setiap hari mengamati perubahan perilaku pada ternaknya, serta melihat ternak apakah ada tanda-tanda sakit dan luka di sekujur tubuhnya.

2. Aspek Manajemen Pemerahan

Manajemen pemerahan sapi perah yang kurang baik akan menyebabkan menurunnya kualitas susu yang dihasilkan. Menurunnya kualitas susu yang dihasilkan menyebabkan rendahnya harga jual susu. Harga jual susu yang rendah akan berpengaruh terhadap pendapatan serta akan berpengaruh terhadap efisiensi penggunaan biaya oleh peternak sapi perah. Oleh karena itu manajemen pemerahan yang baik dan benar sangat dibutuhkan oleh peternak sapi perah saat melakukan proses pemerahan susu sapi perah. 
Tabel 3. Persentase Aplikasi GDFP Aspek Manajemen Pemerahan Peternak Sapi Perah Kemitraan dan Mandiri di Kabupaten Jember

\begin{tabular}{|c|c|c|c|c|}
\hline $\begin{array}{c}\text { Sub Aspek Manajemen } \\
\text { Pemerahan }\end{array}$ & $\begin{array}{c}\text { Peternak } \\
\text { Kemitraan }\end{array}$ & $\begin{array}{c}\text { Persentase } \\
(\%)\end{array}$ & $\begin{array}{l}\text { Peternak } \\
\text { Mandiri }\end{array}$ & $\begin{array}{c}\text { Persentase } \\
(\%)\end{array}$ \\
\hline \multicolumn{5}{|l|}{ Pra pemerahan } \\
\hline 1. Memberikan konsentrat & 6 & $22,27 \%$ & 0 & $0,00 \%$ \\
\hline 2. Membersihkan kandang & 22 & $100,00 \%$ & 6 & $100,00 \%$ \\
\hline 3. Memandikan sapi & 22 & $100,00 \%$ & 6 & $100,00 \%$ \\
\hline 4. Mengikat ekor sapi & 11 & $50,00 \%$ & 2 & $33,33 \%$ \\
\hline $\begin{array}{l}\text { 5. Mencuci ambing dengan } \\
\text { air hangat }\end{array}$ & 3 & $13,64 \%$ & 0 & $0,00 \%$ \\
\hline \multicolumn{5}{|l|}{ Pemerahan } \\
\hline 1. Menggunakan tangan & 22 & $100,00 \%$ & 6 & $100,00 \%$ \\
\hline $\begin{array}{l}\text { 2. Menggunakan mesin } \\
\text { perah }\end{array}$ & 0 & $0,00 \%$ & 0 & $0,00 \%$ \\
\hline \multicolumn{5}{|l|}{ Pasca pemerahan } \\
\hline $\begin{array}{l}\text { 1. Putting direndam dengan } \\
\text { larutan disinfektan }\end{array}$ & 11 & $50,00 \%$ & 0 & $0,00 \%$ \\
\hline Total Menerapkan & & $52,73 \%$ & & $36,67 \%$ \\
\hline
\end{tabular}

Penerapan GDFP sapi perah pada aspek manajemen pemerahan pada peternakan kemitraan lebih besar dari pada aspek manajemen pemerahan peternakan mandiri. Persentase penerapan GDFP aspek manajemen pemerahan peternak mitra sebesar 52,73 \% dan peternak mandiri sebesar $36,67 \%$. Sebanyak $22,27 \%$ peternak mitra memberikan pakan konsentrat sebelum sapi diperah dengan tujuan untuk menenangkan sapi sebelum di perah serta agar kualitas susu tidak turun, sedangkan peternak mitra lainnya dan peternak mandiri tidak menggunakan konsentrat karena harga konsentrat yang cukup mahal.

Kegiatan membersihkan kandang dilakukan oleh semua peternak sebelum pemerahan dilakukan. Setelah membersihkan kandang, peternak langsung memandikan sapi. Menurut Sudono (1999) dalam Simamora dkk (2015), menyarankan sebelum sapi di perah bagian badan sapi sekitar lipat paha dan bagian belakang harus dibersihkan untuk mencegah kotoran yang menempel pada bagian tersebut jatuh kedalam susu pada waktu sapi di perah. Sebelum pemerahan dilakukan, sebanyak $50 \%$ peternak mitra mengikat ekor sapi dengan tali pada salah satu kaki belakang dengan tujuan untuk menghindari sapi mengibas-ngibaskan ekor saat pemerahan, sehingga tidak terjadi kemungkinan kotoran jatuh ke susu karena kibasan ekor sapi. Sebanyak 33,33\% peternak mandiri mengikatkan ekor sapi ke kaki belakang. Sebanyak 13,64\% peternak mitra mencelupkan ambing dengan menggunakan air hangat sebelum pemerahan dilakukan. Sedangkan peternak mandiri tidak menerapkan sub aspek tersebut. Pencucian ambing dengan air hangat sebelum pemerahan bertujuan untuk menghindari pencemaran bakteri dan juga merangsang keluarnya susu dari kelenjar susu dengan optimal (Mahardika dkk., 2016).

Peternak mitra dan peternak mandiri di Kabupaten Jember melakukan pemerahan dengan cara manual atau dengan menggunakan tangan. Setelah pemerahan selesai dilakukan, terdapat 11 orang peternak mitra dengan persentase 50\% mencelupkan ambing ke larutan disinfektan dengan tujuan untuk mencegah masuknya bakteri ke dalam ambing serta mencegah terjadinya penyakit mastitis atau radang ambing yang dapat menurunkan produksi susu. Peternak mitra tersebut menggunakan antiseptik dari daun sirih yang ditanam didepan rumah dan pekarangannya. Sedangkan pada peternak mandiri, tidak ada peternak mandiri yang menerapkan pada sub aspek tersebut, karena minimnya pengetahuan peternak mandiri tentang kemungkinan penyakit yang mungkin terjadi melalui ambing, sedangkan pada peternak mitra memperoleh tambahan pengetahuan melalui sosialisasi Koperasi Galur Murni.

3. Aspek Nutrisi (Pakan dan Air)

Nutrisi (pakan dan air) dalam pemberiannya harus mempertimbangkan kualitas, kuantitas dan kontinuitas. Kualitas merupakan baik buruknya pengaruh pakan terhadap ternak, 
kuantitas menjamin banyak sedikitnya pakan untuk mencukupi kebutuhan ternak, dan kontinuitas menunjukkan kesinambungan ada tidaknya pakan untuk ternak.

Tabel 4. Persentase Aplikasi GDFP Aspek Nutrisi (Pakan dan Air) Peternak Sapi Perah Kemitraan dan Mandiri di Kabupaten Jember

\begin{tabular}{|c|c|c|c|c|}
\hline Sub Aspek Nutrisi & $\begin{array}{c}\text { Peternak } \\
\text { Kemitraan }\end{array}$ & $\begin{array}{l}\text { Persentase } \\
(\%)\end{array}$ & $\begin{array}{l}\text { Peternak } \\
\text { Mandiri }\end{array}$ & $\begin{array}{l}\text { Persentase } \\
(\%)\end{array}$ \\
\hline $\begin{array}{l}\text { Umur 0-1 minggu (Memberikan kolostrum } \\
\text { 3-4 liter) }\end{array}$ & 22 & $100 \%$ & 6 & $100 \%$ \\
\hline $\begin{array}{l}\text { Umur 1-4 minggu (Memberikan air susu 6- } \\
8 \text { liter) }\end{array}$ & 22 & $100 \%$ & 6 & $100 \%$ \\
\hline $\begin{array}{l}\text { Umur } 1-2 \text { bulan (Memberikann air susu } \\
3-4 \text { liter, pakan pemula } 0,5 \mathrm{~kg} \text {, hijauan } \\
2-5 \mathrm{~kg} \text { ) }\end{array}$ & 0 & $0 \%$ & 0 & $0 \%$ \\
\hline $\begin{array}{l}\text { Umur 2-3 bulan (Memberikan air susu 4-5 } \\
\text { liter, pakan pemula } 1 \mathrm{~kg} \text {, hijauan } 2-5 \mathrm{~kg} \text { ) }\end{array}$ & 0 & $0 \%$ & 0 & $0 \%$ \\
\hline $\begin{array}{l}\text { Umur 3-4 bulan (Memberikan air susu 2-4 } \\
\text { liter, pakan pemula } 1 \mathrm{~kg} \text {, hijauan 2-5 kg) }\end{array}$ & 0 & $0 \%$ & 0 & $0 \%$ \\
\hline $\begin{array}{l}\text { Sapi setelah beranak (Memberikan telur, } \\
\text { madu dan gula merah) }\end{array}$ & 17 & $72,27 \%$ & 2 & $33,33 \%$ \\
\hline Total Menerapkan & & $46,21 \%$ & & $38,89 \%$ \\
\hline
\end{tabular}

Semua peternak kemitraan dan semua peternak mandiri memberikan kolostrum pada sapi yang baru lahir/pedet yang masih berumur 0-1 minggu. Kolostrum banyak mengandung zat kekebalan tubuh, protein dan mineral sehingga sangat dibutuhkan oleh pedet yang baru lahir (Khotimah dan Farizal, 2013). Peternak sapi perah kemitraan dan mandiri di Kabupaten Jember tidak memberikan pakan pemula untuk pedet seperti $1 / 2$ bagian tepung bungkil kelapa, $1 / 4$ bagian tepung kacang tanah dan $1 / 4$ bagian tepung jagung. Peternak hanya mendekatkan pakan hijauan didekat pedet. Pakan yang diberikan peternak kemitraan berupa pakan hijauan, konsentrat dan ampas tahu, sedangkan peternak mandiri memberikan pakan berupa pakan hijauan, pakan ampas tahu dan pakan katul. Menurut Asminaya dkk (2018), bahwa variasi jumlah pakan yang diberikan, kecukupan pakan serta ketersediaan air akan mempengaruhi produksi susu.

Penerapan GDFP pada sub aspek pakan sapi perah setelah beranak, peternakan mitra dan peternakan mandiri berturut-turut ialah $72,27 \%$ dan 33,33\%. Terdapat 17 orang peternak mitra dan terdapat 2 orang peternak mandiri yang menerapkan aspek tersebut. Tujuan dari pemberian telur, gula merah dan madu pada sapi perah setelah melahirkan dimaksudkan untuk mengganti tenaga yang terkuras saat sapi perah beranak, oleh karena itu sapi perah harus diberikan pakan rumput secara ad libitum atau tidak terbatas banyaknya.

4. Aspek Kesejahteraan Ternak

Aspek kesejahteraan ternak bertujuan untuk menjamin terpenuhinya kebutuhan dasar dari suatu ternak (Lestari dkk., 2015). Fokus utama aspek kesejahteraan ternak yaitu bebas dari rasa lapar dan haus, bebas dari rasa tidak nyaman, bebas dari rasa sakit, luka dan penyakit serta bebas mengekspresikan tingkah laku alamiah.

Tabel 5. Persentase Aplikasi GDFP Aspek Kesejahteraan Ternak Sapi Perah Peternak Kemitraan dan Mandiri di Kabupaten Jember

\begin{tabular}{lcccc}
\hline \multicolumn{1}{c}{ Sub Aspek Kesejahteraan Ternak } & $\begin{array}{c}\text { Peternak } \\
\text { Kemitraan }\end{array}$ & $\begin{array}{c}\text { Persentase } \\
(\boldsymbol{\%})\end{array}$ & $\begin{array}{c}\text { Peternak } \\
\text { Mandiri }\end{array}$ & $\begin{array}{c}\text { Persentase } \\
(\boldsymbol{\%})\end{array}$ \\
\hline Bebas dari rasa lapar dan haus & 22 & $100,00 \%$ & 6 & $100,00 \%$ \\
$\begin{array}{l}\text { Bebas dari rasa tidak nyaman } \\
\text { Bebas dari rasa sakit, luka dan penyakit }\end{array}$ & 22 & $100,00 \%$ & 4 & $67,00 \%$ \\
$\begin{array}{l}\text { Bebas mengekspresikan tingkah laku } \\
\text { alamiah (bebas bergerak dan berprilaku } \\
\text { normal) }\end{array}$ & 22 & $100,00 \%$ & 6 & $100,00 \%$ \\
\hline Total Menerapkan & 22 & $100,00 \%$ & 4 & $66,67 \%$ \\
\hline
\end{tabular}

Sumber: Data primer diolah (2019) 
Persentase penerapan GDFP sapi perah pada aspek kesejahteraan ternak peternakan kemitraan lebih besar dari pada pada peternakan mandiri. Persentase penerapan GDFP sapi perah pada aspek kesejahteraan ternak peternakan kemitraan sebesar $100 \%$ sedangkan peternakan mandiri sebesar $83,33 \%$. Data pada tabel diatas memperlihatkan bahwa penerapan indikator bebas dari rasa lapar dan haus untuk peternak kemitraan dan peternak mandiri sebesar $100 \%$. Hal tersebut karena semua peternak di daerah penelitian memberikan air minum secara ad libitum atau tidak terbatas. Penerapan indikator bebas dari rasa tidak nyaman peternakan mitra sebesar $100 \%$ dan peternakan mandiri sebesar $67 \%$. Semua peternak mitra menggunakan kandang yang semi terbuka atau tanpa dinding, dengan demikian ventilasi berjalan dengan baik, temperatur tidak panas dan sinar matahari masuk ke kandang. Sedangkan pada kandang sapi perah peternakan mandiri, terdapat 2 orang peternak mandiri yang memiliki kandang bersebelahan dengan dapur dan kandang tersebut tertutup sehingga ventilasi udara berjalan tidak baik dan juga sinar matahari tidak masuk ke dalam kandang.

Penerapan indikator bebas dari sakit, luka dan penyakit peternakan kemitraan dan peternakan mandiri masing-masing sebesar $100 \%$. Peternak langsung melaporkan kepada dokter hewan atau mantri jika ternak nya terserang penyakit, sehingga ternak tersebut langsung di tangani dokter untuk proses kesembuhannya. Penerapan indikator bebas untuk mengekspresikan tingkah laku alamiah peternakan mitra sebesar $100 \%$ dan peternakan mandiri sebesar $66,67 \%$. Terdapat 2 orang peternak mandiri yang memiliki ruangan atau kandang yang sempit sehingga kandang tersebut tidak memberikan kesempatan bagi ternak untuk mengekspresikan pola perilaku normal sebagai wujud kenyamanan hidup.

\section{Aspek Lingkungan}

Peternakan sapi perah dapat menyebabkan adanya dampak lingkungan seperti pencemaran lingkungan di sekitar kandang sapi perah dan juga adanya pencemaran air. Pada umumnya peternak tidak memahami dampak dari adanya peternakan tersebut terhadap lingkungan sehingga peternak membuang kotoran ternaknya sembarangan. . Kesadaran peternak akan kebersihan lingkungan sekitar kandang sangat penting untuk meminimalisir adanya dampak terhadap lingkungan disekitar peternakan sapi perah.

Tabel 6. Persentase Aplikasi GDFP Aspek Lingkungan Peternak Kemitraan dan Mandiri di Jember

\begin{tabular}{lccrc}
\hline \multicolumn{1}{c}{ Sub Aspek Lingkungan } & $\begin{array}{c}\text { Peternak } \\
\text { Kemitraan }\end{array}$ & $\begin{array}{c}\text { Persentase } \\
(\boldsymbol{\%})\end{array}$ & $\begin{array}{c}\text { Peternak } \\
\text { Mandiri }\end{array}$ & $\begin{array}{c}\text { Persentase } \\
(\boldsymbol{\%})\end{array}$ \\
\hline Mendaur ulang kotoran ternak & 2 & $9,09 \%$ & 0 & $0,00 \%$ \\
Memiliki tempat pembuangan kotoran & 7 & $31,82 \%$ & 0 & $0,00 \%$ \\
\hline Total Menerapkan & & $\mathbf{2 0 , 4 5 \%}$ & & $\mathbf{0 , 0 0 \%}$ \\
\hline
\end{tabular}

Sumber: Data primer diolah (2019)

Persentase penerapan GDFP pada aspek lingkungan peternakan kemitraan lebih besar dari pada peternakan mandiri. Hal tersebut karena pada sub aspek mendaur ulang kotoran, terdapat 2 orang peternak mitra yang menerapkan dengan persentase sebesar 9,09\%. Peternak mitra tersebut mendaur ulang kotoran ternak menjadi pupuk kandang. Sedangkan pada peternakan mandiri tidak ada peternak yang mendaur ulang kotoran ternak. Peternak mandiri langsung membuang kotoran tersebut tanpa adanya pengolahan lebih lanjut sehingga tidak ada penerimaan tambahan dari usaha peternakan sapi perah.

Penerapan GDFP pada sub aspek memiliki tempat pembuangan kotoran pada peternakan mitra lebih besar dari pada peternakan mandiri. Penerapan GDFP pada sub aspek memiliki tempat pembuangan kotoran pada peternakan mitra sebesar $31,82 \%$ sedangkan pada peternakan mandiri sebesar $0,00 \%$. Terdapat 7 orang peternak mitra yang memiliki tempat pembuangan kotor. Peternak mitra tersebut hanya menumpuk kotoran sapi di belakang kandangnya dan memberikan pada warga setempat jika ada yang membutuhkan kotoran ternak sapi perah. Sedangkan pada peternakan mandiri, semua peternak mandiri tidak memiliki tempat untuk pembuangan kotoran. Biasanya peternak mandiri langsung membuang kotoran sapi perah ke sungai yang berada di daerah sekitar kandangnya. 


\section{Aspek Manajemen Sosial Ekonomi}

Aspek manajemen sosial ekonomi pada peternakan sapi perah harus memberikan manfaat untuk kepentingan masyarakat yang luas serta dapat menghasilkan keuntungan secara ekonomi yang berkesinambungan bagi para pelaku usaha. Fokus utama sosial responsibility ialah memberikan dampak positif bagi para pekerjanya, dan fokus utama economically sustainable yaitu dapat memberikan keuntungan secara berkesinambungan.

Tabel 7. Persentase Aplikasi GDFP Aspek Manajemen Sosial Ekonomi Peternak Kemitraan dan Mandiri di Kabupaten Jember

\begin{tabular}{lcccc}
\hline \multicolumn{1}{c}{$\begin{array}{c}\text { Sub Aspek Manajemen } \\
\text { Sosial Ekonomi }\end{array}$} & $\begin{array}{c}\text { Peternak } \\
\text { Kemitraan }\end{array}$ & $\begin{array}{c}\text { Persentase } \\
(\mathbf{\%})\end{array}$ & $\begin{array}{c}\text { Peternak } \\
\text { Mandiri }\end{array}$ & $\begin{array}{c}\text { Persentase } \\
(\mathbf{\%})\end{array}$ \\
\hline $\begin{array}{l}\text { Implementasi manajemen SDM yang } \\
\text { efektif dan bertanggung jawab }\end{array}$ & 4 & $18,18 \%$ & 2 & $33,33 \%$ \\
$\begin{array}{l}\text { Menjamin kegiatan di dalam peternakan } \\
\text { dilakukan dengan aman }\end{array}$ & 22 & $100,00 \%$ & 6 & $100,00 \%$ \\
Manajemen keuangan & 13 & $59,09 \%$ & 3 & $50,00 \%$ \\
\hline Total Menerapkan & & $\mathbf{5 9 , 0 9 \%}$ & & $\mathbf{6 1 , 1 1 \%}$ \\
\hline
\end{tabular}

Sumber: Data primer diolah (2019)

Persentase penerapan GDFP peternakan sapi perah pada aspek manajemen sosial ekonomi peternakan mitra sebesar 59,09\% dan peternakan mandiri sebesar $61,11 \%$. Penerapan GDFP pada sub aspek implementasi manajemen SDM yang efektif dan bertanggung jawab pada peternak mitra lebih kecil bila di bandingkan dengan peternak mandiri. Hal tersebut dikarenakan pada peternak mitra mayoritas peternak tidak memiliki pekerja atau staf dari luar. Hanya terdapat 4 orang peternak mitra yang memiliki tenaga kerja di luar anggota keluarga. Pekerjaan di kandang di bantu oleh keluarga (family worker), dengan itu peternak mitra beranggapan tidak perlu menerapkan social responsible karena pekerja merupakan anggota keluarga sendiri. Sedangkan pada peternak mandiri, terdapat 2 orang peternak mandiri yang memiliki pekerja (yang bukan pekerja keluarga) sehingga mereka sangat mementingkan kesejahteraan para pekerja social responsible.

Persentase penerapan GDFP peternakan sapi perah pada sub aspek menjamin kegiatan di dalam peternakan dilakukan dengan aman pada peternakan mitra dan peternakan mandiri sama, yaitu sebesar 100\%, karena para pekerja di kedua usaha peternakan sapi perah tersebut saat bekerja di kandang menggunakan sepatu boot guna menghindari potensi penyakit yang mungkin akan disebabkan oleh kotoran disekitar kandang, serta untuk menghindari kemungkinan luka di kaki akibat benda tajam di sekitar kandang. Menurut Puslitbangnak (Pusat Penelitian dan Pengembangan Ternak) dalam Pranamyaditia (2016), penyakit yang dapat menular dari sapi perah kepada manusia adalah penyakit Anthrax, Rabies, Toxoplasmosis, Scabies, Influenza dan Brucellosis. Penerapan GDFP pada sub aspek manajemen keuangan pada peternakan mitra sebesar 59,09\% dan peternakan mandiri sebesar 50,00\%. Dalam usaha peternakan pasti berkaitan dengan keuangan dan memerlukan suatu buku manajemen keuangan. Isi dari buku manajemen keuangan tersebut berupa seluruh transaksi keuangan yang dikeluarkan peternak maupun keuangan yang diterima peternak di dalam menjalankan usaha sapi perah.

\section{Pendapatan Usaha Ternak Sapi Perah Kemitraan dan Mandiri di Kabupaten Jember}

Usaha ternak sapi perah yang menjalankan kemitraan dan yang mandiri di Kabupaten Jember merupakan salah satu sumber pendapatan bagi peternak sapi perah. Pendapatan yang tinggi serta menguntungkan merupakan hasil ahir yang sangat dinanti dan diharapkan oleh para peternak karena pendapatan tersebut digunakan peternak untuk memenuhi semua kebutuhan hidup dan kesejahteraan keluarganya. Pendapatan dari usaha ternak sapi perah yang tinggi dipengaruhi oleh harga jual susu yang berlaku pada saat penjualan berlangsung serta banyaknya susu yang dihasilkan. Berikut merupakan total biaya, total penerimaan dan total pendapatan usaha ternak sapi perah. 


\section{Biaya Usaha Ternak Sapi Perah}

Faktor biaya dalam suatu usaha peternakan merupakan salah satu faktor yang perlu mendapatkan perhatian bagi setiap pelaku usaha ataupun pelaku ekonomi, termasuk peternakan sapi perah. Penggunaan biaya pada peternakan sapi perah harus diusahakan seminimal mungkin agar mendapatkan keuntungan yang maksimal. Biaya dalam usaha ternak sapi perah terdiri dari biaya tetap dan biaya variabel.

a. Biaya Tetap Usaha Ternak Sapi Perah

Biaya tetap merupakan biaya yang dalam periode tertentu jumlahnya tetap dan tidak bergantung pada jumlah produk yang dihasilkan (Soetriono, 2015). Besarnya komponen masing-masing biaya tetap usaha peternakan sapi perah yang mengikuti kemitraan dan yang mandiri dapat di lihat pada tabel berikut.

Tabel 8. Total Biaya Tetap Peternak Sapi Perah di Kabupaten Jember 2018

\begin{tabular}{lrr}
\hline \multicolumn{1}{c}{ Biaya Tetap (TFC) } & Kemitraan & Mandiri \\
\hline Penyusutan Kandang & 18.530 .000 & 4.650 .000 \\
Penyusutan Milkcan & 3.898 .000 & 270.000 \\
Penyusutan Timba & 802.000 & 162.000 \\
Penyusutan Selang Air & 165.500 & 65.200 \\
Penyusutan Sekrop & 596.667 & 6.667 \\
Penyusutan Sikat & 114.333 & 12.833 \\
Penyusutan Kereta Dorong/Argo & 640.000 & 160.000 \\
Penyusutan Arit/Sabit & 587.500 & 158.750 \\
Penyusutan Tampar & 89.940 & 6.300 \\
Biaya Penyusutan Ternak & 55.700 .000 & 23.100 .000 \\
Pajak Bangunan untuk Kandang & 2.340 .000 & 840.000 \\
\hline Total Biaya Tetap seluruh Peternak & $\mathbf{8 3 . 4 6 3 . 9 4 0}$ & $\mathbf{2 9 . 4 3 1 . 7 5 0}$ \\
\hline
\end{tabular}

Sumber: Data primer diolah (2019)

Besar kecilnya biaya penyusutan kandang tergantung pada besarnya biaya yang dikeluarkan untuk membuat kandang. Semakin luas ataupun semakin bagus kandangnya maka semakin banyak pula biaya yang dikeluarkan untuk membuat kandang. Milkcan merupakan alat berbentuk tabung yang berfungsi khusus sebagai wadah untuk menampung susu segar yang baru di perah. Penggunaan milkcan bertujuan untuk melindungi susu agar tidak terkontaminasi oleh mikroba atau benda asing lainnya seperti debu, kotoran dan lain sebagainya yang bersifat patogen. Besar kecilnya biaya penyusutan peralatan milkcan dipengaruhi oleh harga dari milkcan yang digunakan, jumlah milkcan yang dimiliki serta tergantung dari ukuran milkcan.

Timba yang digunakan peternak sapi perah baik peternak yang mengikuti kemitraan maupun peternak mandiri merupakan timba yang terbuat dari aluminium. Harga timba aluminium berbeda-beda tergantung dari ukurannya. Timba digunakan untuk menampung susu saat pemerahan dilakukan. Timba yang terbuat dari aluminium berfungsi untuk menjaga kualitas susu agar tidak tercampur dengan benda asing. Peralatan sekrop digunakan untuk mengambil atau membuang kotoran sapi perah, selain itu sekrop digunakan untuk membuang limbah padat yang ada di lingkungan sekitar kandang. Peternak sapi perah juga menggunakan sekrop untuk mengaduk atau mencampur pakan untuk sapi perah. Kereta dorong/argo digunakan untuk mengangkut pakan, kotoran atau limbah padat (sampah, sisa-sisa rumput dan limbah lainnya) ke tempat pembuangan. Pajak yang dikeluarkan peternak sapi perah dalam hal ini yaitu pajak bumi bangunan untuk kandang sapi perah.

b. Biaya Variabel Usaha Ternak Sapi Perah

Biaya variabel adalah biaya yang jumlahnya berubah-ubah sesuai dengan jumlah produk yang dihasilkan. Pada biaya variabel, semakin banyak jumlah produk yang dihasilkan maka semakin banyak pula biaya variabel yang dikeluarkan (Soetriono, 2015). 
Tabel 9. Total Biaya Variabel Peternak Sapi Perah Kemitraan dan Mandiri di Kabupaten Jember 2018

\begin{tabular}{lrr}
\hline \multicolumn{1}{c}{ Biaya Variabel (TVC) } & Kemitraan & Mandiri \\
\hline Jumlah Sapi & 147 & 56 \\
Sapi Pedet & 41 & 22 \\
Sapi Dara & 10 & 5 \\
Sapi Jantan & 20 & 2 \\
Sapi Laktasi & 76 & 27 \\
Biaya Pakan Hijauan & 294.732 .000 & 126.936 .000 \\
Jumlah Pakan Hijauan (Kg/Tahun) & 815.040 & 203.760 \\
Jumlah Pakan Hijauan (Kg/Ekor/Tahun) & 7.689 & 5.993 \\
Biaya Ampas Tahu & 164.976 .000 & 132.720 .000 \\
Jumlah Ampas Tahu (Kg/Tahun) & 360.480 & 265.440 \\
Jumlah Ampas Tahu (Kg/Ekor/Tahun) & 4.743 & 9.831 \\
Biaya Konsentrat & 205.776 .000 & - \\
Jumlah Konsentrat (Kg/Tahun) & 61.200 & - \\
Jumlah Konsentrat (Kg/Ekor/Tahun) & 1.654 & - \\
Biaya Katul (Kg) & - & - \\
Jumlah Katul (Kg) & - & 2.160 \\
Jumlah Katul (Kg/Ekor) & - & 350.000 \\
Kesehatan & 1.440 .000 & 600.000 \\
IB & 1.670 .000 & 320.600 .000 \\
Tenaga Kerja & 82.800 .000 & 7.380 .000 \\
Plastik Susu & - & 18.720 .000 \\
Transportasi & 72.696 .000 & 1.440 .000 \\
Listrik & 7.200 .000 & $\mathbf{3 9 9 . 4 2 2 . 0 0 0}$ \\
\hline Total Biaya Variabel seluruh Peternak & $\mathbf{8 3 1 . 2 9 0 . 0 0 0}$ & $\mathbf{4 2 8 . 8 5 3 . 7 5 0}$ \\
\hline Total Biaya (TFC+TVC) seluruh Peternak & $\mathbf{9 1 4 . 7 5 3 . 9 4 0}$ & $\mathbf{7 1 . 4 7 5 . 6 2 5}$ \\
\hline Rata-Rata Total Biaya (TFC+TVC) per & $\mathbf{4 1 . 5 7 9 . 7 2 5}$ & $\mathbf{7 . 6 5 8 . 1 0 3}$ \\
\hline Biaya per Ekor Sapi Perah & $\mathbf{6 . 2 2 2 . 8 1 6}$ & \\
\hline Sumber:Dak & & 5.320 \\
\hline
\end{tabular}

Sumber: Data primer diolah (2019)

Pemberian pakan hijauan peternak kemitraan lebih banyak dari pada pemberian pakan hijauan peternak mandiri. Total pakan hijauan yang dibutuhkan peternak kemitraan sebanyak $7.689 \mathrm{~kg} / \mathrm{ekor} / \mathrm{tahun}$ sedangkan total pakan hijauan yangdibutuhkan peternak mandiri sebanyak $5.993 \mathrm{~kg} / \mathrm{ekor} / \mathrm{tahun}$. Meskipun jumlah pemberian pakan hijauan peternak mandiri lebih sedikit dari pada peternak mandiri, akan tetapi jumlah pemberian pakan ampas tahu peternak mandiri lebih tinggi dari pada peternak mitra.

Pemberian pakan ampas tahu peternak mandiri lebih banyak dari pada pemberian pakan ampas tahu peternak kemitraan, hal ini karena peternak mandiri memberikan pakan hijauan lebih sedikit dibandingkan peternak mitra. Total pakan hijauan yang dibutuhkan peternak mitra untuk mencukupi kebutuhan pakan ampas tahu sapi perah sebanyak $4.743 \mathrm{~kg} / \mathrm{ekor} / \mathrm{tahun}$ sedangkan peternak mandiri membutuhkan ampas tahu sebanyak $9.831 \mathrm{~kg} / \mathrm{ekor} / \mathrm{tahun}$. Ampas tahu diberikan pada sapi perah yang menghasilkan susu/sapi laktasi agar produksi susu sapi perah meningkat.

Pakan konsentrat merupakan suatu bahan pakan yang dipergunakan bersama bahan pakan lain untuk meningkatkan keserasian gizi dari keseluruhan makanan yang disatukan dan dicampur sebagai pakan pelengkap. Pakan yang mengandung konsentrat tinggi akan meningkatkan produksi susu sapi perah (Riski dkk., 2016). Terdapat 6 orang peternak mitra yang menggunakan pakan konsentrat. Harga pakan konsentrat cukup mahal yaitu sebesar Rp 3.200 hingga Rp 3.800 per kilo. Kebutuhan konsentrat satu ekor sapi perah peternak mitra selama satu tahun sebanyak $1.654 \mathrm{~kg} / \mathrm{ekor}$. Tidak semua peternak menggunakan pakan konsentrat dikarenakan harga konsentrat yang cukup mahal. Konsentrat hanya diberikan kepada sapi yang produksi/menghasilkan susu. 
Peternak mandiri di Kecamatan Arjasa semuanya menggunakan pakan katul, sedangkan peternak mitra tidak menggunakan pakan katul untuk usaha ternaknya. Peternak mandiri membutuhkan katul selama satu tahun sebanyak $2.160 \mathrm{~kg} / \mathrm{ekor}$. Katul didapatkan peternak mandiri di selep-selep terdekat. Harga katul mulai dari Rp 1.000 hingga Rp 1.800 per kilo. Katul hanya diberikan kepada sapi yang produksi/sapi laktasi agar produksi susu yang dihasilkan banyak.

Pemeriksaan kesehatan ternak sapi perah dilakukan oleh dokter hewan dan mantri/paramedis. Frekuensi pemeriksaan kesehatan hewan dilakukan oleh sebagian besar peternak secara tidak teratur atau tidak tentu. Bila terdapat ternak yang sakit, beberapa peternak mengobati sendiri dan sebagian peternak lainnya mengobati ternaknya oleh dokter hewan. Metode perkawinan sapi perah yang umum dilakukan oleh peternak dibagi menjadi dua macam yaitu kawin alam dan Inseminasi Buatan (IB). Seluruh peternak mitra dan peternak mandiri mengawinkan ternaknya dengan cara IB, karena perkawinan IB dinilai lebih menguntungkan karena praktis, hemat waktu, hemat tenaga, serta menekan tingkat penyebaran penyakit. Inseminasi dan pemeriksaan kebuntingan dilakukan oleh dokter hewan atau mantri yang langsung mendatangi kandang sapi perahnya peternak.

Para peternak mitra dan peternak mandiri rata-rata mengerjakan sendiri pekerjaanpekerjaan terkait pemeliharaan sapi. Selain itu ada sebagian peternak yang dibantu oleh anggota keluarga mereka yang meliputi istri, anak dan saudara-saudaranya. Upah yang diberikan oleh peternak terhadap tenaga kerja luar keluarga dinilai dengan sejumlah nominal uang yang besarnya tergantung kemampuan setiap unit usaha ternak dalam membayar tenaga kerja luar keluarga tersebut, serta besarnya upah yang diperoleh tenaga kerja berdasarkan kesepakatan yang terbentuk antara pekerja dan pemilik usaha ternak.

Plastik susu digunakan peternak mandiri untuk mengemas susu dari hasil pemerahan untuk dijual ke loper. Susu biasanya dikemas dalam ukuran $1 / 2$ liter. Banyaknya plastik susu yang dibutuhkan peternak mandiri tergantung dari banyaknya susu yang dihasilkan. Peternak sapi perah kemitraan tidak membutuhkan susu karena peternak kemitraan menjual susu ke Koperasi Galur Murni. Biaya transportasi peternak mitra merupakan biaya yang dikeluarkan untuk mendatangkan pakan dan menyetor susu ke Koperasi Galur Murni, sedangkan biaya transportasi peternak mandiri merupakan biaya yang dikeluarkan untuk mendatangkan pakan.

\section{Penerimaan Usaha Ternak Sapi Perah}

Penerimaan yang diperoleh peternak sapi perah selama satu tahun dapat dilihat dari banyaknya susu yang dihasilkan setiap harinya. Sumber penerimaan terbesar peternak sapi perah yaitu susu. Semakin banyak susu yang dihasilkan maka semakin banyak pula penerimaan yang akan di terima peternak.

Tabel 10. Total Penerimaan Susu Peternak Sapi Perah Kemitraan dan Mandiri di Kabupaten Jember Tahun 2018

\begin{tabular}{lrr}
\hline & Kemerimaan & Mandiri \\
\hline Jumlah Sapi & 147 & 56 \\
Sapi Pedet & 41 & 22 \\
Sapi Dara & 10 & 5 \\
Sapi Jantan & 20 & 2 \\
Sapi Laktasi & 76 & 27 \\
Jumlah Produksi (Ltr) & 230,220 & 75,960 \\
Jumlah Produksi (Ltr/Ekor) & 3,029 & 2,813 \\
Rata-Rata Harga Susu (Rp/Ltr) & 4,964 & 6,667 \\
\hline Total Penerimaan Susu seluruh Peternak & $\mathbf{1 , 1 4 2 , 8 1 2 , 0 8 0}$ & $\mathbf{5 0 6 , 4 2 5 , 3 2 0}$ \\
\hline Rata-Rata Penerimaan Susu Peternak per Orang & $\mathbf{5 1 , 9 4 6 , 0 0 4}$ & $\mathbf{8 4 , 4 0 4 , 2 2 0}$ \\
\hline Rata-Rata Penerimaan Susu per Ekor & $\mathbf{1 5 , 0 3 5 , 9 5 6}$ & $\mathbf{1 8 , 7 5 4 , 2 7 1}$ \\
\hline Sumber: Data primer diolah (2019) & &
\end{tabular}


Berdasarkan Tabel 10, dapat diketahui bahwa rata-rata total penerimaan susu peternak (per orang) sapi perah kemitraan lebih rendah dari pada total penerimaan susu peternak (per orang) sapi perah mandiri. Total penerimaan susu peternak (per orang) sapi perah kemitraan selama satu tahun sebesar Rp 51.946.004/tahun sedangkan total penerimaan susu peternak (per orang) sapi perah mandiri selama satu tahun sebesar Rp 84.404.220/tahun. Total penerimaan susu peternak (per orang) sapi perah kemitraan lebih rendah dari pada total penerimaan susu peternak (per orang) sapi perah mandiri karena harga jual susu pada peternak mandiri lebih besar dari pada harga jual susu peternak mitra. Rata-rata harga jual susu pada peternak mandiri sebesar $\mathrm{Rp}$ 6.667/liter sedangkan rata-rata harga susu pada peternak mitra sebesar Rp 4.964/liter. Meskipun penerimaan susu peternak kemitraan lebih rendah dari pada penerimaan susu peternak mandiri akan tetapi produksi susu sapi perah peternak kemitraan lebih tinggi dari pada produksi susu sapi perah peternak mandiri. Jumlah produksi susu (ltr/ekor) peternak kemitraan selama satu tahun sebesar 3.029 liter sedangkan produksi susu (ltr/ekor) pada peternak mandiri selama satu tahun sebesar Rp 2.813 liter. Produksi susu per ekor sapi perah peternak mitra lebih tinggi dari pada produksi susu per ekor sapi perah peternak mandiri karena beberapa orang peternak mitra menggunakan pakan tambahan yiatu pakan konsentrat. Menurut Riski dkk (2016), bahwa pakan yang mengandung konsentrat tinggi akan meningkatkan produksi susu sapi perah.

3. Pendapatan Usaha Ternak Sapi Perah

Pendapatan bersih yang diterima peternak sapi perah merupakan sebuah keuntungan bagi peternak didalam menjalankan usaha peternakan sapi perah. Besarnya keuntungan yang akan di peroleh peternak tergantung dari banyaknya susu yang dihasilkan serta harga jual dari susu tersebut. Apabila susu yang dihasilkan banyak serta harga jual tinggi dengan biaya produksi yang dapat ditekan, maka pendapatan bersih peternak akan semakin meningkat.

Tabel 11. Keuntungan Peternak Sapi Perah Kemitraan dan Mandiri di Kabupaten Jember 2018

\begin{tabular}{lcr}
\hline \multicolumn{1}{c}{ Keuntungan Peternak } & Kemitraan & Mandiri \\
\hline TR & 51.946 .004 & 84.404 .220 \\
TC & 41.579 .725 & 71.475 .625 \\
\hline Total Keuntungan per Peternak & $\mathbf{1 0 . 3 3 6 . 2 7 9}$ & $\mathbf{1 2 . 9 2 8 . 5 9 5}$ \\
\hline Sumber: Data primer diolah (2019) & &
\end{tabular}

Berdasarkan Tabel 12 di atas, dapat diketahui bahwa peternak sapi perah yang mengikuti kemitraan dan peternak sapi perah mandiri di Kabupaten Jember sama-sama menguntungkan karena penerimaan lebih besar dari pada total biaya. Sumber penerimaan peternak sapi perah tersebut berasal dari penjualan susu setiap harinya. Total pendapatan bersih/keuntungan yang diterima oleh peternak mitra sebesar Rp 10.336.279/orang/tahun dan total pendapatan bersih/keuntungan peternak mandiri sebesar Rp 12.928.595/orang/tahun. Berikut merupakan data terkait pendapatan bersih per ekor ternak sapi perah di Jember.

Tabel 12. Total Biaya, Total Penerimaan dan Pendapatan Bersih per Ekor Sapi Perah Peternak Mitra dan Peternak Mandiri di Kabupaten Jember Tahun 2018

\begin{tabular}{lrr}
\hline & Kemitraan & Mandiri \\
\hline Rata-Rata Total Penerimaan (Rp/Ekor/Tahun) & $15,035,956$ & $18,754,271$ \\
Rata-Rata Total Biaya (Rp/Ekor/Tahun) & $6,222,816$ & $7,658,103$ \\
Pendapatan (Rp/Ekor/Tahun) & $8,813,140$ & $11,096,168$ \\
\hline
\end{tabular}

Sumber: Data primer diolah (2019)

Pada Tabel 12, dapat diketahui bahwa pendapatan per ekor sapi perah peternak mitra lebih rendah dibandingkan pendapatan per ekor peternak sapi perah mandiri. Pendapatan per ekor sapi perah peternak mandiri sebesar Rp 8.813.149/ekor/tahun sedangkan pendapatan per ekor sapi perah peternak mandiri sebesar Rp 11.096.168/ekor/tahun. Pendapatan per ekor sapi perah peternak mandiri lebih tinggi dari pada pendapatan per ekor sapi perah peternak mitra disebabkan karena harga jual susu peternak mandiri lebih tinggi dari pada harga jual susu 
peternak mitra. Pendapatan per ekor sapi perah peternak mitra dan peternak mandiri sama-sama menguntungkan karena penerimaan lebih tinggi dari pada total biaya yang dikeluarkan.

\section{Efisiensi Penggunaan Biaya Usaha Ternak Sapi Perah Kemitraan dan Mandiri di Kabupaten Jember}

Besar kecilnya nilai $\mathrm{R} / \mathrm{C}$ rasio tergantung dari penerimaan dan biaya yang dikeluarkan di dalam menjalankan usaha peternakan sapi perah. R/C rasio lebih besar dari satu maka penggunaan biaya usaha ternak sapi perah tersebut efisien, sedangkan jika nilai $\mathrm{R} / \mathrm{C}$ rasio kurang dari satu maka penggunaan biaya usaha ternak sapi perah tersebut tidak efisien.

Tabel 13. Efisiensi Penggunaan Biaya per Peternak Sapi Perah Kemitraan dan Mandiri di Kabupaten Jember Tahun 2018

\begin{tabular}{lrr}
\hline & Kemitraan & Mandiri \\
\hline TR & 51.946 .004 & 84.404 .220 \\
TC & 41.579 .725 & 71.475 .625 \\
Efisiensi R/C & $\mathbf{1 , 2 5}$ & $\mathbf{1 , 1 8}$ \\
\hline
\end{tabular}

Sumber: Data primer diolah (2019)

Berdasarkan Tabel 13, dapat diketahui bahwa nilai efisiensi R/C rasio peternak kemitraan lebih tinggi dari pada nilai efisiensi R/C rasio peternak mandiri, karena biaya yang digunakan peternak mandiri lebih banyak di bandingkan penggunaan biaya peternak mitra. Nilai efisiensi $\mathrm{R} / \mathrm{C}$ rasio peternak kemitraan sebesar 1,25 dan nilai efisiensi $\mathrm{R} / \mathrm{C}$ rasio peternak mandiri sebesar 1,18. Nilai R/C rasio peternak kemitraan sebesar 1,25 dapat diartikan setiap pengeluaran $\mathrm{Rp} 1,00$ oleh peternak mitra akan mendapatkan penerimaan sebesar $\mathrm{Rp} 1,25$. Nilai $\mathrm{R} / \mathrm{c}$ rasio peternak mandiri sebesar 1,18 dapat diartikan setiap pengeluaran $\mathrm{Rp}$ 1,00 oleh peternak mandiri akan mendapatkan penerimaan sebesar Rp 1,18. Hal tersebut menunjukkan bahwa usaha peternakan sapi perah peternak kemitraan dan peternak mandiri di Kabupaten Jember sudah efisien karena hasil perbandingan penerimaan dengan pengeluaran (biaya) lebih besar dari 1.

\section{KESIMPULAN}

1. Tingkat penerapan GDFP peternak kemitraan cenderung lebih tinggi dari pada tingkat penerapan GDFP peternak mandiri. Rata-rata tingkat penerapan GDFP peternak mitra sebesar 62,96\% artinya peternak kemitraan telah mampu menerapkan GDFP sebesar $62,96 \%$. Rata-rata tingkat penerapan GDFP peternak mandiri sebesar 53,33\% artinya peternak mandiri mampu menerapkan GDFP sebesar 53,33\%. Tingkat penerapan GDFP peternak sapi perah kemitraan pada aspek kesehatan ternak sebesar $100 \%$ dan peternak mandiri sebesar $100 \%$, aspek manajemen pemerahan peternak mitra sebesar $52,73 \%$ dan peternak mandiri sebesar $36,67 \%$, aspek nutrisi (pakan dan air) peternak mitra sebesar 46,21\% dan peternak mandiri sebesar 38,89, aspek kesejahteraan ternak peternak mitra sebesar $100 \%$ dan peternak mandiri sebesar $83,33 \%$, aspek lingkungan peternak mitra sebesar $20,45 \%$ dan peternak mandiri sebesar $0,00 \%$, aspek manajemen sosial ekonomi peternak mitra sebesar $59,09 \%$ dan peternak mandiri sebesar $61,11 \%$.

2. Jenis usaha peternakan sapi perah baik kemitraan maupun mandiri di Kabupaten Jember sama-sama menguntungkan. Besarnya pendapatan per ekor sapi perah peternak kemitraan sebesar Rp 8.813.140/tahun dan pendapatan bersih per ekor sapi perah peternak mandiri sebesar Rp 11.096.168/tahun.

3. Efisiensi penggunaan biaya pada usaha ternak sapi perah kemitraan dan mandiri samasama efisien. Nilai efisiensi R/C rasio usaha peternakan sapi perah kemitraan sebesar 1,25 artinya setiap pengeluaran $\mathrm{Rp} 1,00$ oleh peternak mitra akan mendapatkan penerimaan sebesar Rp 1,25. Nilai efisiensi R/C rasio usaha peternakan mandiri sebesar peternak mandiri sebesar 1,18 artinya setiap pengeluaran Rp 1,00 oleh peternak mandiri akan mendapatkan penerimaan sebesar Rp 1,18. 


\section{DAFTAR PUSTAKA}

Anggraeni, A. dan E. M. (2016). Evaluasi Aspek Teknis Pemeliharaan Sapi Perah Menuju Good Dairy Farming Practices pada Peternakan Sapi Perah Rakyat Pondok Ranggon. Agripet, 16(2), 90-96.

Asminaya, N. S dan B. P. Purwanto, A. A. dan N. (2018). Evaluasi Aspek Teknis Pemeliharaan Sapi Perah Berdasarkan Good Dairy Farming Practices (GDFP) di Peternakan Rakyat Cibungbulang. Ilmu Dan Teknologi Peternakan Tropis, 5(3), 79-87.

Isnia, M., Y. H. dan A. K. (2017). nalisis Manajemen Rantai Pasok Susu Sapi Perah pada Koperasi Peternak Galur Murni di Kecamatan Sumberbaru Kabupaten Jember. JSEP, 10(1), 65-77.

Kementerian Pertanian. (2016). Outlook Susu Komoditas Pertanian Subsektor Peternakan. https://doi.org/http://epublikasi.setjen.pertanian.go.id

Khotimah, K. dan F. (2013). Kualitas Mikrobiologi Kolostrum Sapi Perah FH pada Waktu Pemerahan yang berbeda di Peternakan Rakyat. Ilmu Ternak, 13, 13-17.

Lestari, N. F., M. M. dan A. F. (2015). Hubungan Antara Penerapan Good Dairy Farming Practice dengan Tingkat Pendapatan Peternak pada Peternakan Sapi Perah Rakyat (Suatu Kasus di Wilayah Kerja KPBS Pangalengan Kabupaten Bandung). Mahasiswa, 4(3), 1-16.

Mahardika, H. A., P. T. dan P. S. (2016). engaruh Suhu Air Pencucian Ambing dan Teat Dipping terhadap Jumlah Produksi, Kualitas dan Jumlah Sel Somatik Susu pada Sapi Peranakan Friesian Holstein. Buletin Peternakan, 40, 11-20.

Otoluwa, M. A., A. H. S. Salendu., A. K. R. dan M. T. M. (2016). Prospek Pengembangan Usaha Ternak Sapi Potong Di Kecamatan Bolangitang Timur Kabupaten Bolaang Mongondow Utara. Zootek, 36(1), 191-197.

P. Riski, B. P. P. dan A. A. (2016). Produksi dan Kualitas Susu Sapi FH Laktasi yang Diberi Pakan Daun Pelepah Sawit. Ilmu Produksi Dan Teknologi Hasil Peternakan, 4(3), 345349.

Pranamyaditia, C. D. (2016). Risiko Keselamatan dan Kesehatan Kerja pada Pekerja Peternakan Sapi di PT X Cabang Kota Kediri. Occupational Safety and Health, 5(1), 1-10.

Priska. K. Londa, P. O.V Waleleng, R. A. J. L.-A. dan F. H. E. (2013). Analisis Break Even Point (BEP) Usaha Ternak Sapi Perah "TAREKAT MSC" Di Kelurahan Pinaras Kota Tomohon. Zootek, 32(1), 158-166.

Sari, D. I. (2018). Analisis Depresiasi Aktiva Tetap Metode Garis Lurusdan Jumlah Angka Tahun PT Adira Dinamika. Moneter, V, 86-92.

Simamora, T., A. M. F. dan A. A. A. (2015). Evaluasi Aspek Teknis Peternakan Sapi Perah Rakyat di Kabupaten Karo Sumatera Utara. Ilmu Produksi Dan Teknologi Hasil Peternakan, 3(1), 52-58.

Soetriono. (2015). Daya Saing Agribisnis Kopi Robusta. Malang: Surya Pena Gemilang.

Statistik, B. P. (2018). Produksi Susu Segar menurut Provinsi di Indonesia. [Serial Online]. https://doi.org/http://bps.go.id [18 Oktober 2018] 